\section{The debate on whaling}

SIR - D. S. Butterworth's Commentary "Science and sentimentality" (Nature 357, 532; 1992) appeared during a meeting of the International Whaling Commission (IWC), events at which refute Butterworth's thesis. That thesis seems in essence to be that other scientists have "obfuscated", "moved goal-posts" and generally behaved unethically in acting as mere dupes of governments with secret "animal rights" agendas. He cannot substantiate it.

New rules for setting catch limits were adopted by a resolution opposed only by Norway. They take into account the real uncertainties, not imaginary ones as Butterworth would have Nature readers believe. Norway and Iceland have concluded that they will lead to unacceptably low catch limits and have taken unilateral action accordingly.

Most IWC members - nearly all of them ex-whaling countries - have been working for five years towards a management regime for renewed commercial whaling that fulfils the objectives of the convention under with the commission operates. "The real debate" is not "between some countries wishing to preserve industries ... and others wanting [whales] classed as sacrosanct" but rather between that majority which insists that resumed commercial whaling must be such that there is little chance of further depletions and that already depleted stocks are restored to high, productive levels, and a minority of three (now two) whose primary interest is in taking profitable catches in the immediate future.

The majority has placed conditions on the implementation of the new rules: that more attention be given to devising ways of hunting and killing whales humanely, and that effective international monitoring of the application of the rules (including standards for scientific data) be instituted. Neither condition is new, but neither is acceptable to the Norwegian authorities. A statement by Norway's foreign minister on 22 July, calling minke whales "rats of the sea", illustrates how emotions are manipulated so that rational discussion of science and management is prejudiced.

There is a strong moral component of the debate, but it does not involve "animal rights". Rather, it concerns sustainability of use, inter-generational equity and the rule of international law, under which whales have a unique status as "highly migratory marine animals", whose exploitation and conservation are to be governed through the IWC.

As to the matter of MSY rates (a measure of potential productivity), the consensus was that a range of from 1 to 4 per cent is justified by the sparse data. Butterworth has recently been arguing that much higher rates are more "reasonable"; their adoption would, of course, give correspondingly higher immediate catch limits, and greatly increase the chances of inadvertent depletions of stocks.

Butterworth's claim that the term 'protected status' has been "skilfully" misused by "conservationists" to generate alarm of 'danger of extinction' is false. That the 'protection' level chosen in 1975, and reaffirmed in 1991, concerns catch-maximization is well-known to all who have followed the proceedings of the IWC.

Butterworth thinks the proposal by France for a whale sanctuary suggests "desperation among animal rightists". The French government is hardly one usually associated with 'animal rights' policies although it is well known for recent successful actions for the conservation of Antarctica. Most members praised the proposal. Seventeen of them co-sponsored a resolution, which the commission adopted, to ensure that it would be definitely considered next year. There is no evidence that any of those governments wish to abandon or distort science.

\section{Sidney Holt}

International Fund for Animal Welfare,

Podere II Falco,

06062 Città della Pieve (PG), Italy

\section{$\mathrm{CO}_{2}$ emissions}

SIR - Being reminded by leading articles in Nature that the recent Earth Summit in Rio de Janeiro that was being sponsored by the United Nations (UN) and remembering that there have long been complaints that the West shoulders an excessive proportion of the costs of running that organization prompted an idea that could provide a painless solution to the lack of a serious proposal for carbon dioxide regulation. If the 1992 UN contributions are recalculated per ton of carbon dioxide emissions documented for 1982 , the contributions of North America and Europe are then

\section{Funding errors}

SIR - J. Katz (Nature 358, 10; 1992) has, with astonishing brevity, epitomized the errors almost universally committed in the funding of research: emphasis on the number rather than the quality of publications, funding of promising research projects rather than of individuals of proven ability, the existence of large research groups, where freedom of creative thought is absent, and the support of consensus science, with the end-result that new and original ideas are discouraged by the present system. I hope Katz's letter is read, and understood, by some of the higher echelons in the field of research funding.

I agree with both the points raised and the arguments brought forward by Katz on these issues, with one notable exception. He believes that fraud in research is committed because the stakes are high. But a person who can perpetrate fraud in research is simply unsuitable as a scientist. In the words of Plato: "Science without justice, and also without every other kind of virtue, is closer to cunning rather than wisdom". If we begin to rationalize lying in science we will end up in an "Erehwon" type of scientific community, where it will be de rigueur to express sympathy to perpetrators of scientific fraud.

\section{Emmanuel T. Rakitzis}

Department of Biological Chemistry,

University of Athens Medical School,

Athens 11527 ,

Greece

seen to be the same as the rest of the world (see table). Were the UN Earth Conference to agree that contributions be recalculated according to national 1992 carbon dioxide emissions, there could be no dispute as little would change but the world would see that our leaders have agreed on the importance of carbon dioxide emissions being centre stage in their deliberations.

R. T. D. Oliver

Department of Medical Oncology,

London Hospital Medical College,

Turner Street, London E1 2AD, UK

1. Marland, G. The Prospect of Solving the $\mathrm{CO}_{2}$ Problem through Global Representation, National Technical Information Service Document TRO39, 4-8 (US Department of Commerce, Virginia, 1988)
UN SUBSCRIPTIONS ADJUSTED PER TON OF $\mathrm{CO}_{2}$ EMISSION

\section{UN contribution}

\begin{tabular}{lcccc}
\cline { 4 - 4 } & & & & \\
\cline { 3 - 4 } & $\begin{array}{c}\text { Population } \\
\text { (millions, 1985) }\end{array}$ & $\mathrm{CO}_{2}$ emission & Total & $\mathrm{CO}_{2}$ emission \\
North America & 237 & $10^{6}$ ton 1982) & $($ Emillion) & \\
Europe & 250 & 1,243 & 271 & $£ 0.22$ \\
Rest of World & 4,355 & 2,280 & 280 & $£ 0.22$ \\
Total & 4,842 & 4,749 & 487 & $£ 0.22$ \\
\end{tabular}

